\title{
XRD and FTIR Analysis of Magnesium Substituted Tricalcium Calcium Phosphate Using a Wet Precipitation Method
}

\author{
Asmaa Massit ${ }^{1}\left(\mathbb{D}\right.$, Ahmed El Yacoubi ${ }^{1(\mathbb{D})}$, Abdelilah Kholtei ${ }^{2}$ (D), Brahim Chafik El Idrissi ${ }^{1, *(\mathbb{D})}$ \\ Laboratory of Advanced Materials and Process Engineering, Faculty of Sciences, Ibn Tofail University, Kenitra, Morocco \\ 2 Laboratory of Chemistry Biology Applied to Environment, Mouly Ismail University, Faculty of Sciences, BP11201 \\ Meknes, Morocco \\ * Correspondence: chidrissi@yahoo.fr;
}

Scopus Author ID 6602822327

Received: 2.06.2020; Revised: 3.07.2020; Accepted: 5.07.2020; Published: 9.07.2020

\begin{abstract}
The incorporation of magnesium $(\mathrm{Mg})$ in tricalcium phosphate (TCP) was prepared through a precipitation method followed by calcination at $850{ }^{\circ} \mathrm{C}$ in air. Calcium hydroxide, $\left(\mathrm{Ca}(\mathrm{OH})_{2}\right)_{\text {, }}$ phosphoric acid, $\left(\mathrm{H}_{3} \mathrm{PO}_{4}\right)$, and magnesium chloride $\left(\mathrm{MgCl}_{2} \cdot 6 \mathrm{H}_{2} \mathrm{O}\right)$ with a $\mathrm{Ca} / \mathrm{P}$ ratio of 1.5 , were mixed as the precursor materials. The concentration of added $\mathrm{Mg}$ was varied with respect to calcium $(\mathrm{Ca})$ precursor molarity as such $\mathrm{Mg} /(\mathrm{Ca}+\mathrm{Mg})$ molar ratio was $0.05,0.10$, and 0.15 , while the $(\mathrm{Ca}+\mathrm{Mg}) / \mathrm{P}$ ratio was maintained at 1.50 throughout the experiment. The influence of Mg-doped TCP on phase composition, chemical structure, and a functional group at different weight percentages were accomplished through X-ray diffraction (XRD), inductively coupled plasma optical emission spectroscopy (ICP-OES) and Fourier Transform Infrared Spectroscopy (FTIR) analyses. Based in the results of this research, the presence of magnesium led to the formation of $\mathrm{Mg}$-doped calcium-deficient apatite (MgCDA) at $80^{\circ} \mathrm{C}$ and $\mathrm{Mg}$-doped $\beta$-TCP at $850^{\circ} \mathrm{C}$; the incorporation of $\mathrm{Mg}$ into the TCP phase causing an expansion of the lattice and increase in the lattice parameter. This result could be considered rather unusual.
\end{abstract}

Keywords: Tricalcium phosphate; Magnesium; precipitation method; XRD and FTIR.

(C) 2020 by the authors. This article is an open-access article distributed under the terms and conditions of the Creative Commons Attribution (CC BY) license (https://creativecommons.org/licenses/by/4.0/).

\section{Introduction}

Hydroxyapatite $\left(\mathrm{Ca}_{10}\left(\mathrm{PO}_{4}\right)_{6}(\mathrm{OH})_{2}, \mathrm{HA}\right)$ and $\beta$-tricalcium phosphate $(\beta$-TCP, $\beta$ $\left.\mathrm{Ca}_{3}\left(\mathrm{PO}_{4}\right)_{2}\right)$ have been considered the most promising materials for both dental and orthopedic applications, because of their chemical similarity to that of human hard tissue [1-5]. Owing to their favorable biological response, these materials have been applied in a wide range of typologies like cement [6,7]. Nevertheless, their applications are limited due to some disadvantages. For example, HA shows a limited ability to stimulate the development of new bone tissue and does not degrade significantly [8]. The weak mechanical properties of $\beta$-TCP ceramics, due to its brittleness and insufficient compaction, are limiting its use to non-loadbearing applications.

The most thoroughly investigated material considering ionic substitution is $\beta$-TCP [913]. In turn, magnesium is definitely the most widely incorporated dopant into its crystal lattice [14-16]. Magnesium ( $\mathrm{Mg}$ ) ion is an essential trace element where it is the fourth cation in the human body that plays an important role in preventing osteoporosis and increase the 
regeneration of bone in biomedical applications. Generally, the magnesium content in the human body is known between 0.5 to $1.5 \mathrm{wt} \%$ [17-20]. Bone contains $0.72 \mathrm{wt} \%$ of magnesium that are required in the growth of osteoblast and osteoplastic activity of the bone. $\mathrm{Mg}$ and $\mathrm{Ca}$ provide strong and healthy bones and reduce osteoporosis. Osteoporosis happens due to the high content of calcium with low content of magnesium that affects the fracture of bone [21]. Also, doping $\beta$-TCP with Mg ions decreases its solubility [22]. Synthesis methods, such as precipitation [23,24], wet mixing [25,26], mechanochemical-hydrothermal synthesis [27,28], in-situ synthesis [29], solid-state reactions [30,31], sol-gel [32,33] and room temperature synthesis method [34] have been applied. The preparation of TCP through aqueous precipitation usually involves the synthesis of calcium-deficient apatite (CDA) by adjusting the initial $\mathrm{Ca} / \mathrm{P}$ molar ratio of the precursors to 1.50 and subsequent calcination in the range of $700-800^{\circ} \mathrm{C}$ to form TCP with the loss of water as represented in the equation (1) :

$$
\mathrm{Ca} 9\left(\mathrm{HPO}_{4}\right)\left(\mathrm{PO}_{4}\right)_{5} \mathrm{OH} \rightarrow 3 \mathrm{Ca}_{3}\left(\mathrm{PO}_{4}\right)_{2}+\mathrm{H}_{2} \mathrm{O}
$$

However, there are very few studies available in the literature on the synthesis and characterization of tricalcium calcium phosphate-containing magnesium prepared via the wet precipitation method. In this work, precursor materials that are normally used to synthesize hydroxyapatite (HA) directly were adopted to obtain $\beta$-TCP and Mg- $\beta$ TCP. The influence of the $\mathrm{Mg}$ substitution in the lattice parameters of the unit cell $\beta$-TCP was evaluated.

\section{Materials and Methods}

Tricalcium phosphate and $\mathrm{Mg}$-substituted tricalcium phosphate with $\mathrm{Mg} /(\mathrm{Ca}+\mathrm{Mg})$ ratio equal to 0 (TCP0), 0.05 (TCP1), 0.10 (TCP2) and 0.15 (TCP3) were synthesized by precipitation method [35] from an aqueous solution of calcium hydroxide $\left[\mathrm{Ca}(\mathrm{OH})_{2}\right]$ (Scharlau, Spain) orthophosphoric acid $\left[\mathrm{H}_{3} \mathrm{PO}_{4}\right]$ (Riedel-de Haën, $85 \%$ ) and magnesium chloride $\left[\mathrm{MgCl}_{2} .6 \mathrm{H}_{2} \mathrm{O}\right]$ (Riedel-de Haën, Germany) at $40^{\circ} \mathrm{C}, \mathrm{pH}=9$ (concentrations of the precursors are depicted in Table 1). A predetermined concentration of $\mathrm{MgCl}_{2} \cdot 6 \mathrm{H}_{2} \mathrm{O}$ was added slowly to the continuously stirred solution of $\mathrm{Ca}(\mathrm{OH})_{2}$. The aqueous solution of $\mathrm{H}_{3} \mathrm{PO}_{4}$ was added rapidly to the above solution containing calcium and Magnesium ions using a vigorous stirring. According to Table 1, the nominal composition, in terms of $(\mathrm{Ca}+\mathrm{Mg}) / \mathrm{P}$ ratio, was maintained at 1.50. Precipitates were aged in mother liquors at room temperature for $24 \mathrm{~h}$, washed with distilled water, vacuum filtered, and finally dried $24 \mathrm{~h}$ in an oven at $80^{\circ} \mathrm{C}$. The dried samples were further calcined $12 \mathrm{~h}$ at $850^{\circ} \mathrm{C}$. In the case of the Mg-TCP precursor, it has been assumed that magnesium ions would substitute for the calcium site in the apatite lattice.

Table 1. Molar concentrations of the precursors $\mathrm{Ca}, \mathrm{P}$, and $\mathrm{Mg}$ used in the synthesis.

\begin{tabular}{l|c|cc|c|c} 
Sample code & Molar & \multicolumn{2}{|c|}{ Concentrations } & $\mathbf{C a} / \mathbf{P}$ ratio & $(\mathbf{C a}+\mathbf{M g}) / \mathbf{P}$ ratio \\
\hline & $\mathbf{C a}$ & $\mathbf{P}$ & $\mathbf{M g}$ & & \\
\hline TCP0 & 0.600 & 0.400 & 0.000 & 1.50 & 1.50 \\
\hline TCP1 & 0.570 & 0.400 & 0.030 & 1.42 & 1.50 \\
\hline TCP2 & 0.540 & 0.400 & 0.060 & 1.35 & 1.50 \\
\hline TCP3 & 0.510 & 0.400 & 0.090 & 1.27 & 1.50
\end{tabular}

$\mathrm{X}$-ray diffraction characterization of all batches of as-prepared and calcined Mg-TCP powders was performed using $\mathrm{Cu} \mathrm{K} \alpha$ radiation. Samples were analyzed over a $2 \theta$ range of $10-$ $80^{\circ}$ with a sampling interval of $0.07^{\circ}$ (XRD, Kristalloflex D-500, Siemens Analytical X-ray Instrument Inc., Madison, WI). Crystallographic identification of the synthesized phases was accomplished by comparing the experimental XRD patterns to standards compiled by the Joint 
Committee on Powder Diffraction and Standards (JCPDS), which were card \#09- 0169 for TCP $\left(\mathrm{a}=10.432(3) \mathrm{A}^{\circ}, \mathrm{b}=10.432(3) \mathrm{A}^{\circ}, \mathrm{c}=37.39 \mathrm{~A}^{\circ}\right.$, space group $R 3 \mathrm{c}$ (167), theoretical density $3.072 \mathrm{~g} / \mathrm{cm}^{3}, \mathrm{~V}=3520.91 \mathrm{~A}^{\circ 3}, \mathrm{Z}=21$ ) and $\# 33-0297$ for $\beta-\mathrm{Ca}_{2} \mathrm{P}_{2} \mathrm{O}_{7}$.

The average crystallite size $\mathrm{D}(\mathrm{hkl})$ in $\mathrm{nm}$ was estimated following Debey-Scherrer equation [30]:

$$
\operatorname{Dhkl}=\frac{\mathrm{k} \lambda}{\beta \cos \theta}
$$

where $\mathrm{K}$ is the shape factor equal to $0.9, \lambda$ is the $\mathrm{X}$-rays wavelength (equal to $1.5406 \mathrm{~A}^{\circ}$ for $\mathrm{Cu}$ Ka radiation), $\theta$ is the Bragg's diffraction angle (in degrees), and $\beta$ is the full width at half

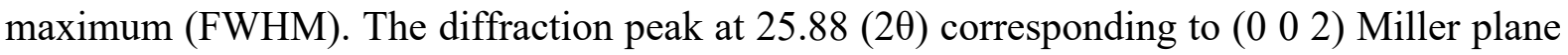
family of apatite lattice (JCPDS file \#09-0432), was chosen to calculate the average crystal size along to the crystallographic axis c. The length of coherent domains $\mathrm{D}\left(\begin{array}{lll}2 & 0 & 10\end{array}\right)$ in TCP crystallites was also calculated using the line broadening of the (2 0 10) peak (diffraction angle $\left.2 \theta\left(31.08^{\circ}\right)\right)$ [36], applying the Scherrer's equation to XRD spectra of samples calcined at $850^{\circ} \mathrm{C}$.

Cell parameters of the tricalcium phosphate phase were estimated through the algorithm DICVOL 06 (Fullprof-suite software), using XRD diffraction patterns of samples calcined.

The chemical structure of powders was evaluated in the vibration range of 400-4000 $\mathrm{cm}^{-1}$, using an Infrared Fourier Spectrometer (VERTEX 70, Genesis Series, resolution 4, scans $20)$. For this, $1 \%$ of the powder was mixed and ground with $99 \% \mathrm{KBr}$.

\section{Results and Discussion}

XRD patterns of all as-prepared TCP and Mg-TCP powders are compared in Figure 1. All samples showed the typical diffraction pattern of the calcium-deficient hydroxyapatite (CDA) as from the perfect match with HA (\#09-0432 card) characteristic reflections. In the pure TCP and the Mg-TCP samples, no other XRD peaks except for those derived from the CDA phase were observed. The substitution of $\mathrm{Mg}$ did not appear to affect the diffraction patterns of the as-prepared powders. Moreover, due to the existence of $\mathrm{Mg}$, the diffraction peaks slightly shifted to larger angles in the pattern (figure 2), indicating the incorporation of Mg into $\beta$-TCP.

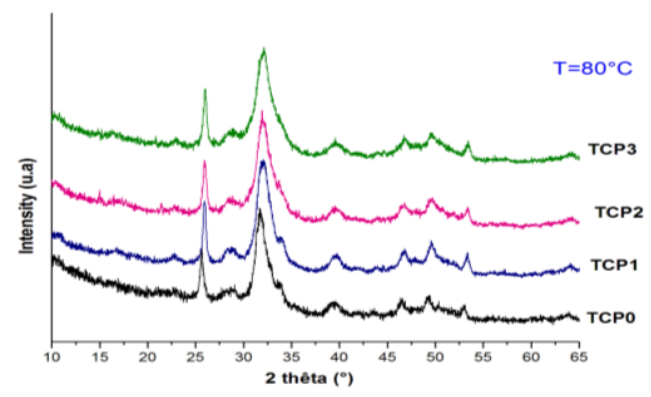

Figure 1. XRD patterns of as-dried TCP and Mg-TCP precursors.

With increasing the amount of $\mathrm{Mg}$ in calcium-deficient apatite, the crystallinity of the apatite phase gradually decreased as manifested by the increased broadening of their XRD peaks. The gradual decrease of crystallinity is one of the indications suggesting increasing $\mathrm{Mg}$ incorporation in the CDA lattice. The calculated crystallite sizes are $25.5 \mathrm{~nm}$ (TCP0), $22.4 \mathrm{~nm}$ (TCP1), $20.7 \mathrm{~nm}$ (TCP2), and $20.5 \mathrm{~nm}$ (TCP3), respectively. The presence of $\mathrm{Mg}^{2+}$ ions seems to make the crystallization more difficult, as also observed in previous works for MgTCP powders [31, 37]. CDA powders are produced according to the reaction (1): 


\section{$(9-3 \mathrm{x}) \mathrm{Ca}(\mathrm{OH})_{2}+6 \mathrm{H}_{3} \mathrm{PO}_{4}+3 \mathrm{xMgCl}_{2} .6 \mathrm{H}_{2} \mathrm{O} \rightarrow \mathrm{Ca}(9-3 \mathrm{x}) \mathrm{Mg}_{3 x}\left(\mathrm{HPO}_{4}\right)\left(\mathrm{PO}_{4}\right)_{5}(\mathrm{OH})+6 \mathrm{xHCl}+$ $(17+12 x) \mathrm{H}_{2} \mathrm{O}$}

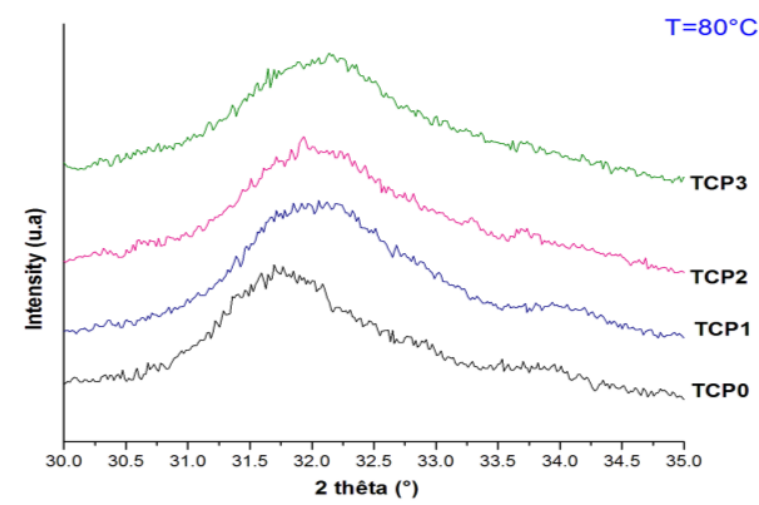

Figure 2. X-ray diffraction showing peak shifts to larger angles after incorporation of $\mathrm{Mg}$.

It is important to underline that TCP cannot be synthesized directly in aqueous solution by the wet method. The precipitate is an apatitic tricalcium phosphate $\mathrm{Ca}_{9}\left(\mathrm{HPO}_{4}\right)\left(\mathrm{PO}_{4}\right)_{5}(\mathrm{OH})$, consisting of calcium-deficient hydroxyapatite, $\mathrm{Ca}_{10}\left(\mathrm{PO}_{4}\right)_{6}(\mathrm{OH})_{2}$ where $\mathrm{HPO}_{4}{ }^{2-}$ ion partially substitutes the $\mathrm{PO}_{4}{ }^{3-}$ groups. The crystallization of anhydrous $\beta$-TCP requires further calcination of the apatitic compound at temperatures over $750^{\circ} \mathrm{C}$ [38]. For this reason, it is essential to carry out $\mathrm{X}$-ray diffraction analysis on samples that have been heating treated at temperatures higher than $750^{\circ} \mathrm{C}$ in order to assess the effect of chemical changes on the phase composition and formation of pure $\beta$-tricalcium phosphate with $\mathrm{Mg}$ incorporation in its structure.

ICP was adopted to evaluate the actual Mg-doped amounts of the samples (TCP0, TCP1, TCP2, and TCP3). As shown in Table 2, the actual Mg-doped amounts of all the samples were closed to the designed ratios, but all were a little higher than that. $\mathrm{Ca}(4)$ in $\beta$-TCP has a lower occupancy factor of 0.43(4) [39]. Because of the shorter distance of $\mathrm{Mg}-\mathrm{O}$, after $\mathrm{Mg}$ is replaced with $\mathrm{Ca}$, it altered the crystal lattice, which may intensify the vacancy of $\mathrm{Ca}$ ions, leading to the increase in $\mathrm{Mg} /(\mathrm{Ca}+\mathrm{Mg})$ ratio.

Table 2. Molar ratio of $(\mathrm{Ca}+\mathrm{Mg}) / \mathrm{P}$ and $\mathrm{Mg} /(\mathrm{Ca}+\mathrm{Mg})$ of the samples.

\begin{tabular}{l|l|l} 
Samples & $(\mathbf{C a}+\mathbf{M g}) / \mathbf{P}$ & $\mathbf{M g} / \mathbf{C a}+\mathbf{M g})$ \\
\hline TCP0 & 1.501 & 0 \\
\hline TCP1 & 1.496 & $5.813 \%$ \\
\hline TCP2 & 1,478 & $11.744 \%$ \\
\hline TCP3 & 1.488 & $15.124 \%$
\end{tabular}

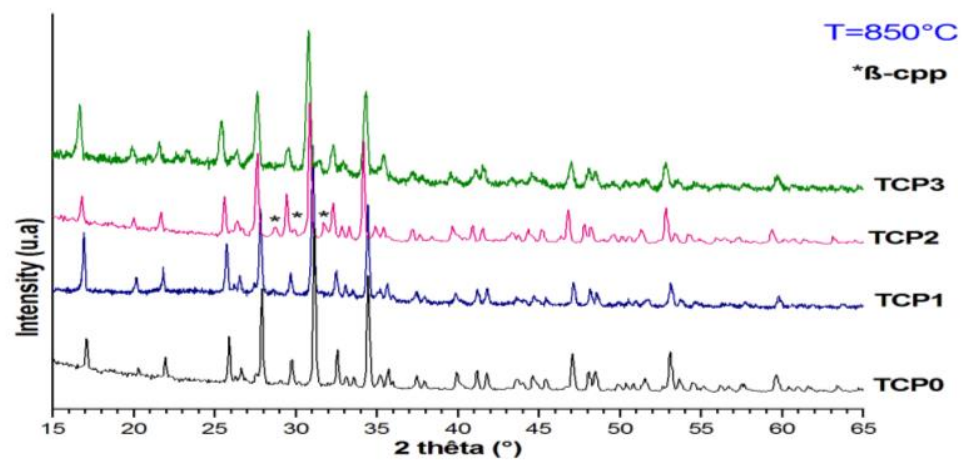

Figure 3. XRD spectra of the TCP Mg-TCP precursors calcined at $850^{\circ} \mathrm{C}$. 
The XRD profiles (figure 3) of calcined undoped and Mg-doped CDA powders showed that all the calcined samples were completely transformed to $\beta$-TCP and Mg- $\beta$-TCP, respectively, according to equation (2):

$$
\mathrm{Ca}(9-\mathrm{x}) \mathrm{Mg}_{\mathrm{x}}\left(\mathrm{HPO}_{4}\right)\left(\mathrm{PO}_{4}\right)_{5}(\mathrm{OH}) \rightarrow 3\left(\mathrm{Ca}_{3}-(\mathrm{x} / 3) \mathrm{Mg}_{\mathrm{x} / 3}\right)\left(\mathrm{PO}_{4}\right)_{2}+\mathrm{H}_{2} \mathrm{O}
$$

In these powders, the precursors $(\mathrm{Ca}+\mathrm{Mg}) / \mathrm{P}$ molar ratio during synthesis was adjusted to 1.50 to ensure the incorporation of $\mathrm{Mg}$ into $\beta$-TCP. In the $\mathrm{Mg}$-TCP samples with $\mathrm{Mg} /(\mathrm{Ca}+\mathrm{Mg})=0.05$ and 0.15 (TCP1 and TCP3 samples), no other XRD peaks except for those derived from the TCP phase were observed, while peaks indicating the presence of $\mathrm{Ca}_{2} \mathrm{P}_{2} \mathrm{O}_{7}$ $(\beta-\mathrm{CPP})$ were observed in the sample with $\mathrm{Mg} /(\mathrm{Ca}+\mathrm{Mg})=0.10(\mathrm{TCP} 2)$. When analyzing the vibrational bands of the samples doped with $\mathrm{Mg}^{2+}$, as observed in Figure 3, we realized that there were substitutions in the connection sites with phosphate, which would release $\mathrm{Ca}^{2+}$ ions and affect the chemical composition of the material, leading to the formation of new phases. Then, the substitution of $\mathrm{Ca}^{2+}$ by $\mathrm{Mg}^{2+}$ occurred at these sites and decreased the $\mathrm{Ca} / \mathrm{P}$ ratio by changing the crystalline structure of $\beta$-TCP to $\beta$-CPP. With increasing Mg substitution, the XRD peaks became gradually broader and weaker. This effect could be explained by decreased crystallite size and increased lattice disorder associated with increasing Mg substitution in the TCP lattice. Peak positions shift to lower angles and are also observed (figure 4), which indicates lattice expansion caused by magnesium substitution. These observed peaks shift in the XRD pattern is a clear indication of the incorporation of Mg into the TCP phase, causing an expansion of the lattice and an increase in the lattice parameter. This could be considered somewhat unusual since $\mathrm{Mg}^{2+}$ is smaller in size (ionic radius $\sim 0.65 \AA$ ) compared to $\mathrm{Ca}^{2+}$ (ionic radius $\sim 0.99 \AA$ ). There are five crystallographically independent sites, $\mathrm{Ca}(1)-\mathrm{Ca}(5)$, in the unit cell of $\beta$-TCP [40], but $\mathrm{Ca}^{2+}$ can be replaced by $\mathrm{Mg}^{2+}$ only on $\mathrm{Ca}(4)$ and $\mathrm{Ca}(5)$ sites in the $\beta$ TCP structure. According to Enderle et al. [41], the $\mathrm{Ca}^{2+}$ up to $10 \mathrm{~mol} \% \mathrm{Mg}^{2+}$ is preferably replaced on the six-fold coordinated $\mathrm{Ca}(5)$ site resulting in a decrease of both lattice parameters. Replacement of $\mathrm{Ca}^{2+}$ on the nine-fold coordinated $\mathrm{Ca}(4)$ site by $\mathrm{Mg}^{2+}$ does not significantly take place until the $\mathrm{Ca}(5)$ site is completely occupied by $\mathrm{Mg}^{2+}$. Above $10 \mathrm{~mol} \%$ replacement by $\mathrm{Mg}^{2+}$, the nine-fold coordinated $\mathrm{Ca}(4)$ site is occupied by $\mathrm{Mg}^{2+}$, and the lattice parameters increase until maximum substitution. Hence the $\mathrm{Mg}^{2+}$ may be probably occupying an interstitial site rather than an actual lattice site causing increase cell parameter a.

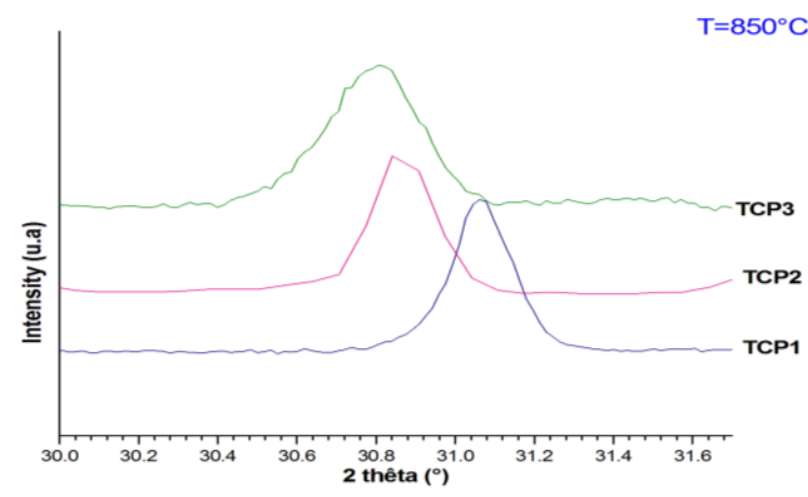

Figure 4. X-ray diffraction showing peak shifts after Mg is substituted indicative of lattice expansion.

Calculated cell parameters are reported in Table 3. An increase of ' $a$ ' and 'c' was detected. Finally, the mean crystallite size of pure TCP and Mg-TCP precursors calcined at 
$850^{\circ} \mathrm{C}$, i.e., TCP0, TCP1, TCP2, and TCP3 was estimated as about $47.1 \mathrm{~nm}, 46.7 \mathrm{~nm}, 42.9$ and $31.9 \mathrm{~nm}$, respectively.

Table 3. Calculated cell parameters of $\beta-\mathrm{Mg}$ - substituted tricalcium phosphate calcined at $850^{\circ} \mathrm{C}$.

\begin{tabular}{l|c|c|c|c} 
Sample & $\mathbf{M g} /(\mathbf{C a}+\mathbf{M g})$ & $\mathbf{a}\left(\mathbf{A}^{\circ}\right)$ & $\mathbf{c}\left(\mathbf{A}^{\circ}\right)$ & $\mathbf{V}\left(\mathbf{A}^{\circ \mathbf{3}}\right)$ \\
\hline TCP0 & 0 & $10.402(4)$ & $37.293(5)$ & 3495 \\
TCP1 & 0.05 & $10.412(4)$ & $37.403(2)$ & 3511 \\
\hline TCP2 & 0.10 & $10.427(7)$ & $37.415(8)$ & 3522 \\
TCP3 & 0.15 & $10.440(5)$ & $37.424(3)$ & 3532
\end{tabular}

The FTIR analysis (Figure 5) of the as-prepared CDA and Mg-CDA powders was in good accordance with the results of the XRD analysis. Selected FTIR spectra to show the characteristic bands of $\mathrm{Ca}$ deficient apatite groups: v4 $\mathrm{PO}_{4}{ }^{3-}\left(560-600 \mathrm{~cm}^{-1}\right), v 1 \mathrm{PO}_{4}{ }^{3-}(960$ $\left.\mathrm{cm}^{-1}\right)$, and $v 3 \mathrm{PO}_{4}{ }^{3-}\left(1020-1120 \mathrm{~cm}^{-1}\right)$. The band at $875 \mathrm{~cm}^{-1}$ is ascribed to $\mathrm{HPO}_{4}{ }^{2-}$ stretching mode of hydrogen phosphate groups. The very weak peaks located at $630 \mathrm{~cm}^{-1}$ and $3568 \mathrm{~cm}^{-1}$ were attributed to $\mathrm{OH}^{-}$. The amount of carbonate detected at 1420 and $1456 \mathrm{~cm}^{-1}$. The presence of functional groups such as $\mathrm{OH}^{-}, \mathrm{HPO}_{4}{ }^{2-}$ and $\mathrm{PO}_{4}{ }^{3-}$ confirms that the powders prepared and then dried at $80^{\circ} \mathrm{C}$ are only DCA and $\mathrm{Mg}$-DCA structures.

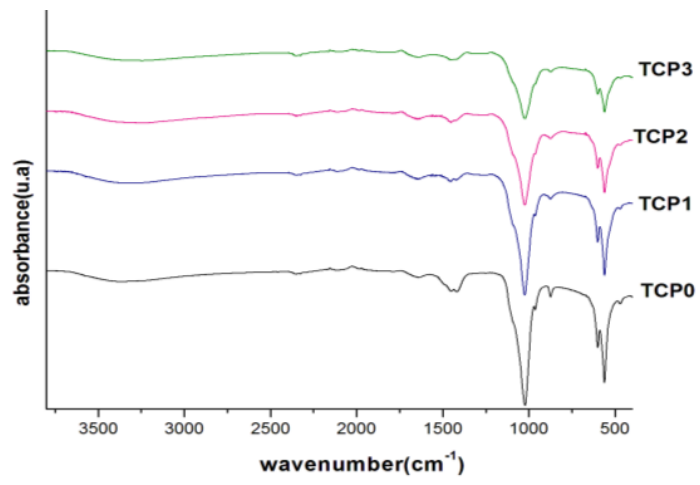

Figure 5. FTIR spectra of as-dried TCP and Mg-TCP precursors.

The FTIR spectra of TCP and Mg-TCP precursors calcined at $850^{\circ} \mathrm{C}$ are presented in Figure 6. As can be seen, the FTIR results of magnesium substituted tricalcium phosphate indicate the typical peaks characteristic of pure $\beta$-TCP [42]. The infrared absorption bands located at 1132, 1030,990,960,610, and $560 \mathrm{~cm}^{-1}$ contribute to the confirmation of $\mathrm{PO}_{4}$ tetrahedra of $\beta-\mathrm{Ca}_{3}\left(\mathrm{PO}_{4}\right)_{2}$ structure [43]. The TCP2 sample showed additional peaks at 756 and $1213 \mathrm{~cm}^{-1}$ ascribed to the symmetrical stretching vibration of the $\mathrm{P}-\mathrm{O}-\mathrm{P}$ group, which is characteristic of the calcium pyrophosphate phase $\mathrm{Ca}_{2} \mathrm{P}_{2} \mathrm{O}_{7}$ in agreement with the previous XRD results.

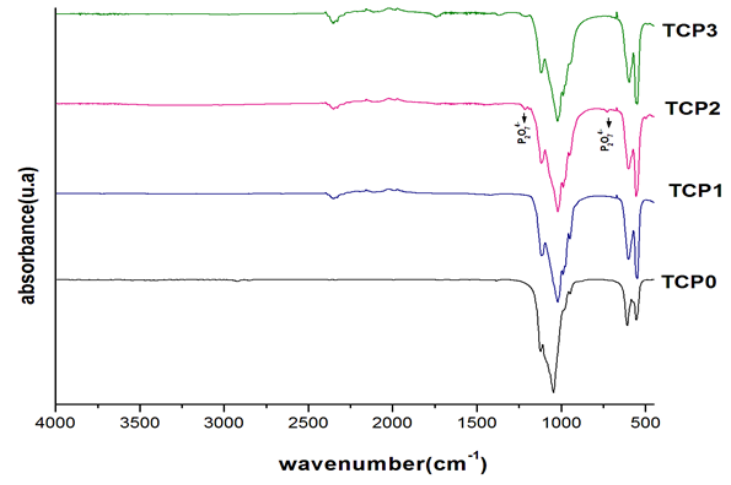

Figure 6. FTIR spectra of TCP and Mg-TCP precursors calcined at $850^{\circ} \mathrm{C}$. 


\section{Conclusions}

Pure and $\mathrm{Mg}$-doped calcium phosphate compounds were synthesized via the precipitation method starting from $\mathrm{Ca}(\mathrm{OH})_{2}, \mathrm{H}_{3} \mathrm{PO}_{4}$, and $\mathrm{MgCl}_{2} \cdot 6 \mathrm{H}_{2} \mathrm{O}$. The thermal behavior at $80^{\circ} \mathrm{C}$ and $850^{\circ} \mathrm{C}$ of synthesized powders were studied with the help of FTIR and XRD data. Based on the results of this research, nanosized phase $\beta$-Mg-TCP powders were obtained by thermal treatment at $850^{\circ} \mathrm{C}$. The crystallite size of $\mathrm{Mg}$-CDA decreased with increasing $\mathrm{Mg}^{2+}$ content. It could be observed that both the cell parameters and cell volume increase, unusually, with $\mathrm{Mg}$ content.

\section{Funding}

This research received no external funding.

\section{Acknowledgments}

This research has no acknowledgment.

\section{Conflicts of Interest}

The authors declare no conflict of interest.

\section{References}

1. Kannan, S.; Goetz-Neunhoeffer, F.; Neubauer, J.; and Ferreiraw, J.M.F. Ionic substitutions in biphasic hydroxyapatite and $\beta$-tricalcium phosphate mixtures: structural analysis by rietveld refinement. J. Am. Ceram. Soc 2008, 91, 1-12, https://doi.org/10.1111/j.1551-2916.2007.02117.x.

2. Jorge, E.; Chanfrau, R. Evaluation of the influence of microwave irradiation on a bacterial composed of three phases of calcium phosphates. Biointerface Research in Applied Chemistry 2020, 10, 5141-5144, https://doi.org/10.33263/BRIAC102.141144.

3. Jorge, E.; Chanfrau, R.; Yaymarilis, V.P.; Antonio, C.G. Ultrasonic Application and spry drying during amorphous calcium phosphate synthesis. Letters in Applied NanoBionScience 2019, 8, 711-714, https://doi.org/10.33263/LIANBS84.711714.

4. Ruiz-Aguilar, C.; Olivares-Pinto, U.; Drew, R.A.L.; Aguilar-Reyes, E.A.; Alfonso, I. Porogen Effect on Structural and Physical Properties of $\beta$-TCP Scaffolds for Bone Tissue Regeneration. IRBM 2020, (In Press). https://doi.org/10.1016/j.irbm.2020.05.007.

5. Gallo, M.; Tadier, S.; Meille, S.; Chevalier, J. Resorption of calcium phosphate materials: considerations on the in vitro evaluation. Journal of the European Ceramic Society 2018, 38, 3, 899-914, https://doi.org/10.1016/j.jeurceramsoc.2017.07.004.

6. Fathi, M.; Kholtei, A.; EL Youbi, S.; Chafik El Idrissi, B. Setting Preperties of Calcium Phosphate Bone Cement. Materials Today: Proceedings 2019, 13, 876-881, https://doi.org/10.1016/j.matpr.2019.04.051.

7. Fathi, M.; Massit, A.; El Yacoubi, A.; Chafik El Idrissi, B. Development of an apatitic calcium phosphate cements: effect of liquid/poder ratio on the setting time. Mor. J. Chem 2020, 8, 176-183.

8. Bianco, A.; Cacciotti, I.; Lombardi, M.; Montanaro, L. Si-substituted hydroxyapatite nanopowders: Synthesis, thermal stability and sinterability. Materials Research Bulletin 2009, 44, 345-354, https://doi.org/10.1016/j.materresbull.2008.05.013.

9. Boanini, E.; Gazzano, M.; Nervi, C.; Chierotti, M.R.; Rubini, K.; Gobetto, R.; Bigi, A. Strontium and Zinc Substitution in $\beta$-Tricalcium Phosphate: An X-ray Diffraction, Solid State NMR and ATR-FTIR Study. $J$. Funct. Biomater 2019, 10, https://doi.org/10.3390/jfb10020020.

10. Altomare, M.; Rizzi, R.; Rossi, M.; El Khouri, A.; Elaatmani, M.; Paterlini, V.; Ventura, G. D.; F. Capitelli. New $\mathrm{Ca}_{2.90}\left(\mathrm{Me}^{2+}\right)_{0.10}\left(\mathrm{PO}_{4}\right)_{2} \beta$-tricalcium Phosphates with $\mathrm{Me}^{2+}=\mathrm{Mn}, \mathrm{Ni}, \mathrm{Cu}$ : Synthesis, Crystal-Chemistry, and Luminescence Properties, Crystals 2019, 9, https://doi.org/10.3390/cryst9060288.

11. Tkachenko, S.; Horynová, M.; Casas-Luna, M.; Diaz-de-la-Torre, S.; Dvořák, K.; Celko, L.; Kaiser, J.; Montufar, E.B. Strength and fracture mechanism of iron reinforced tricalcium phosphate cement fabricated by spark plasma sintering. J. Mech. Behav. Biomed. Mater. 2018, 81, 16-25, https://doi.org/10.1016/j.jmbbm.2018.02.016.

12. Sinusaite, L.; Renner, A.M.; Schütz, M.B.; Antuzevics, A.; Rogulis, U.; Grigoraviciute-Puroniene, I.; Mathur, S.; Zarkov, A. Effect of Mn doping on the low-temperature synthesis of tricalcium phosphate (TCP) 
polymorphs. Journal of the European Ceramic Society 2019, 39, 3257-3263, https://doi.org/10.1016/j.jeurceramsoc.2019.03.057.

13. Aurélie, J.; Gaulier, M.; Duval, A.; Renaudin, R. Silver Doping Mechanism in Bioceramics-From $\mathrm{Ag}^{+}$:Doped HAp to Ag॰/BCP Nanocomposite. Crystals 2019, 9, https://doi.org/10.3390/cryst9070326.

14. Nikaido, T.; Tsuru, K.; Munar, M.; Maruta, M.; Matsuya, S.; Nakamura, S.; Ishikawa, K. Fabrication of $\beta$ TCP foam: Effects of magnesium oxide as phase stabilizer on its properties. Ceramics International 2015, 41, 14245-14250, https://doi.org/10.1016/j.ceramint.2015.07.053.

15. Salma-Ancane, A.; Stipniece, L.; Putnins, A.; Berzina-Cimdina, L. Development of Mg-containing porous $\beta$-tricalcium phosphate scaffolds for bone repair. Ceram. Int 2015, 41, 4996-5004. https://doi.org/10.1016/j.ceramint.2014.12.065.

16. Frasnelli, M.; Pedranz, A.; Biesuz, M.; Dirè, S.; Sglavo, V.M. Flash sintering of Mg-doped tricalcium phosphate (TCP) nanopowders. Journal of the European Ceramic Society 2019,39, 3883-3892, https://doi.org/10.1016/j.jeurceramsoc.2019.05.007.

17. García-Páez, H.; García Carrodeguas, R.; De Aza, A.H.; Baudín, C.; Pena, P. Effect of Mg and Si cosubstitution on microstructure and strength of tricalcium phosphate ceramics. J. Mech. Behav. Biomed. Mater 2014, 30, 1-15, https://doi.org/10.1016/j.jmbbm.2013.10.011.

18. Adzila, S.; Kanasan, N.; Fahrul, M.; Mubarak, A.; Arifin, T.; Nasrull, M, \& Rahman, A. Synthesis and characterization of magnesium doped calcium phosphate for bone implant application. J. ofEng. and Appl. Sci 2016, 11, 1819-6608.

19. Nanthini, K.; Adzila, S.; Suid, M.S.; Panerselvan, G. Preparation and Characterization of Hydroxyapatite/Sodium Alginate Biocomposites for Bone Implant Application. AIP Proceedings 2016, 1756, 5162-5165, https://doi.org/10.1063/1.4958749.

20. Kanasan, N.; Adzila, S.; Azimahmustaffa, N.; Gurubaran, P. The Effect of Sodium Alginate on the Properties of Hydroxyapatite. Procedia Engineering 2017, https://doi.org/10.1016/j.proeng.2017.04.115.

21. Kanasan, N.; Adzila, S.; Rahman, H.A.; Bano, N.; and Panerselvan, G.; Hidayati, N.A. FTIR and XRD Evaluation of Magnesium Doped Hydroxyapatite/Sodium Alginate Powder by Precipitation Method. Key Engineering Materials 2018, 791, 45-49, https://doi.org/10.4028/www.scientific.net/KEM.791.45.

22. Gallo, M.; Le Gars Santoni, B.; Douillard, T.; Zhang, F.; Gremillard, L.; Dolder, S.; Hofstetter, W.; Meille, S.; Bohner, M.; Chevalier, J.; Tadier, S.; Hofstetter, W.;Meille, S.; Bohner, M.; Chevalier, J.; Tadier, S. Effect of grain orientation and magnesium doping on $\beta$-tricalcium phosphate resorption behavior. Acta Biomaterialia 2019, 89, 391-402, https://doi.org/10.1016/j.actbio.2019.02.045.

23. Sader, M.S.; Legeros, R.Z.; Soares, G.A. Human osteoblasts adhesion and proliferation on magnesiumsubstituted tricalcium phosphate dense tablets. J. Mater. Sci. Mater. Med 2009, 20, 521-527, https://doi.org/10.1007/s10856-008-3610-3.

24. Kubarev, O.L.; Barinov, S.M.; Komlev, V.S. Magnesium distribution in the synthesis of biphasic calcium phosphates. Dokl. Chem 2008, 418, 44-46, https://doi.org/10.1134/S0012500808020067.

25. Zyman, Z.; Tkachenk, M.; Epple, M.; Polyakov, M.; Nabok M. Magnesium-substituted hydroxyapatite ceramics. Mat. wiss. u. Werkstofftech 2006, 37, 474-478, https://doi.org/10.1002/mawe.200600022.

26. Tan, C.Y.; Aw, K.L.; Yeo, W.H.; Ramesh, S.; Hamdi, M, Sopyan, I. Influence of magnesium doping in hydroxyapatite ceramics. Biomed. 2008 , 21, 326-329, https://doi.org/10.1007/978-3-540-69139-6_83.

27. Suchanek, W.L.; Byrappa, K.; Shuk, P.; Riman, R.E. Preparation of magnesium-substituted hydroxyapatite powders by the mechanochemical-hydrothermal method. Biomaterials 2004, 25, 46474657, https://doi.org/10.1016/j.biomaterials.2003.12.008.

28. Suchanek, W.L.; Byrappa, K.; Shuk, P.; Riman, R.E.; Janas, V.F, TenHuisen, K.S. Mechanochemicalhydrothermal synthesis of calcium phosphate powders with coupled magnesium and carbonate substitution. J. Solid State Chem. 2004, 177, 793-799, https://doi.org/10.1016/j.jssc.2003.09.012.

29. Lee, D.; Sfeir, C.; Kumta, P.N. Novel in-situ synthesis and characterization of nanostructured magnesium substituted $\beta$-tricalcium phosphate $\beta$-TCMP. Mater. Sci. Eng. C. 2009, 29, 69-77, https://doi.org/10.1016/j.msec.2008.05.017.

30. Tardei, C.; Grigore, F.; Pasuk, I.; Stoleriu, S. The study of $\mathrm{Mg}^{2+} / \mathrm{Ca}^{2+}$ substitution of $\beta$-tricalcium phosphate. J. Optoelectron. Adv. Mater. 2006, 8, 568-571.

31. Frasnelli, M.; Sglavo, V.M. Effect of $\mathrm{Mg}^{2+}$ doping on $\beta$ - $\alpha$ phase transition in tricalcium phosphate ceramics. Acta Biomater. 2016, 33, 283-9, https://doi.org/10.1016/j.actbio.2016.01.015.

32. Ruiz-Aguilar, C.; Olivares-Pinto, U.; Aguilar-Reyes, E.A.; López-Juárez, R.; Alfonso, I. Characterization of $\beta$-tricalcium phosphate powders synthesized by sol-gel and mechanosynthesis. Boletín de la Sociedad Española de Cerámica y Vidrio 2018, 57, 213-220, https://doi.org/10.1016/j.bsecv.2018.04.004.

33. Gozalian, A.; Behnamghader, A.; Daliri, M.; Moshkforoush, A. Synthesis and thermal behavior of Mg-doped calcium phosphate nanopowders via the sol gel method. Scientia Iranica FO 2011, 18, 1614-1622, https://doi.org/10.1016/j.scient.2011.11.014.

34. Liu, L.; Wu, Y.; Xu, C.; Suchun Yu.; Wu, X.; Dai, H. Synthesis, Characterization of Nano- $\boldsymbol{\beta}$-Tricalcium Phosphate and the Inhibition on Hepatocellular Carcinoma Cells. Journal of Nanomaterials 2018, 2018, https://doi.org/10.1155/2018/7083416. 
35. Massit, A.; El Yacoubi, A.; Rezzouk, A.; Chafik El Idrissi, B. Thermal Behavior of Mg-Doped CalciumDeficient Apatite and Stabilization of $\beta$ Tricalcium Phosphate.. Biointerface Research in Applied Chemistry 2020, 10, 6, 6837-6845.

36. Cacciotti, I.; Bianco, A. High thermally stable Mg-substituted tricalcium phosphate via precipitation, Ceramics International. 2011, 37, 127-137, https://doi.org/10.1016/j.ceramint.2010.08.023.

37. Frasnelli, M.; Pedranz, A.; Biesuz, M.; Dirè, S.; Sglavo, V.M. Flash sintering of Mg-doped tricalcium phosphate (TCP) nanopowders. Journal of European Ceramic societ. 2019, 39, 3883-3892, https://doi.org/10.1016/j.jeurceramsoc.2019.05.007.

38. Destainville, A.; Champion, E.; Bernache-Assollant, D.; La Borde, E. Synthesis, characterization and thermal behaviour of apatitic tricalcium phosphate.Mater. Chem. Phys. 2003, 80, 269-277, https://doi.org/10.1016/S0254-0584(02)00466-2.

39. Guo, X.; Long,Y.; Li, W.; Dai, H. Osteogenic effects of magnesium substitution in nanostructured btricalcium phosphate produced by microwave synthesis. J Mater Sci 2019, 54, 11197-11212, https://doi.org/10.1007/s10853-019-03674-7.

40. Yashima, M.; Sakai, A.; Kamiyama, T.; Hoshikawa, A. Crystal structure analysis of $\beta$-tricalcium phosphate $\mathrm{Ca}_{3}\left(\mathrm{PO}_{4}\right)_{2}$ by neutron powder diffraction. J. Solid State Chem 2003, 175, 272-277, https://doi.org/10.1016/S0022-4596(03)00279-2.

41. Enderle, R.; Gotz-Neunhoeffer, F.; Gobbels, M.; Muller, F.A.; Greil, P. Influence of magnesium doping on the phase transformation temperature of $\beta$-TCP ceramics examined by Rietveld refinement. Biomaterials 2005, 26, 3379-3384. https://doi.org/10.1016/j.biomaterials.2004.09.017.

42. Fathi, M.; El Yacoubi, A.; Massit, A.; Chafik El Idrissi, B. Wet chemical method for preparing high purity $\beta$ and $\alpha$-tricalcium phosphate crystalline powders. Int J Sci Eng Res 2015, 6, 139-142.

43. Massit, A.; Fathi, M.; El Yacoubi, A.; Kholtei, A.; Chafik El Idrissi, B. Effect of physical and chemical parameters on the $\beta$-Tricalcium phosphate synthesized by the wet chemical method. Med. Journal of Cem 2018, 7, https://doi.org/10.13171/mjc7310268-elidrissi. 